\title{
A Central Asian début in ET89
}

Since ET was founded in 1985 its quarterly issues have covered many locales and kinds and uses of English, but only now has it become possible to focus on Central Asia. The cover article in our 89th issue arrived as a complete surprise - and a most welcome one at that. Not only does it deal with English in Uzbekistan; it touches on the Uzbek language itself and the changing role of Russian in Central Asia.

English had no significant role in the vast territory formerly known (in English) as the Soviet Union or USSR or (more simply, traditionally, and inaccurately) as Russia. The trans-Eurasian empire of both the czars and the commissars now survives only in the history books, and a new patchwork of autonomous names and shapes has appeared in atlases published in the years after 1989.

Many 'emerging', 'underdeveloped', or 'post-colonial' nationstates have become everyday names in the world's Western-dominated news media: the former Belgian Congo is now simply 'Congo', the British colonies of Tanganyika and Zanzibar now make up Tanzania, and a once German then divided British and French West African territory is now 'Cameroon', which belongs only to itself. Many such nation-states and UN members have had associations with one or more European language(s) - and most have in recent times either retained English or added it alongside an already available ex-imperial language, such as French in Tunisia and in Vietnam, and Spanish in the Philippines and Argentina.

However, as long as the Soviet Union existed, the names and natures of territories within its bounds remained less well known elsewhere, and, if known, primarily via Moscow. Perhaps the best known beyond this 'Second World', apart from Russia itself, have been Armenia and Georgia.

It is therefore a matter of particular interest (and satisfaction), in the present typically varied issue, to highlight the land of the Uzbeks, from which Dilbarhon Hasanova has emailed a brisk account of rising local interest in English. Her welcome contribution whets the appetite for more on the role(s) of this and other languages, not only among the '-stans' but elsewhere across the Eurasian north, from Oslo to Vladivostok.

Tom McArthur

The editorial policy of English Today is to provide a focus or forum for all sorts of news and opinion from around the world. The points of view of individual writers are as a consequence their own, and do not reflect the opinion of the editorial board. In addition, wherever feasible, ET generally leaves unchanged the orthography (normally British or American) and the usage of individual contributors, although the editorial style of the journal itself is that of Cambridge University Press.

English Today (ISSN 0266-0784) is published quarterly by Cambridge University Press, The Edinburgh Building, Shaftesbury Road, Cambridge CB2 2RU, UK / Cambridge University Press, 40 West 20th Street, New York, N.Y. 10011-4211.

○ Cambridge University Press 2007. No contents may be reproduced by any means without the permission of Cambridge University Press.

Subscriptions: The 2007 subscription price (excluding VAT) for four issues for libraries and institutions, which includes print and electronic access, is f98 outside of North America; $f 34$ for individuals; $f 25$ for students and the retired. The electronic-only price available to institutional subscribers is f92. Prices include delivery by air where appropriate. Apply to Jane Crossland at the above address.

Advertising Sales: write to the Advertising Promoter at the above address. Email:

journals_marketing@cambridge.org

USA, CANADA AND MEXICO:

Subscriptions: The 2007 subscription price (excluding VAT) for four issues for libraries and institutions, which includes print and electronic access, is $\$ 163$ in USA, Canada and Mexico; \$54 for individuals; $\$ 39$ for students and the retired. The electronic-only price available to institutional subscribers is $\$ 150$. Apply to Marianne Headrick at Cambridge University Press,

40 West 20th Street, New York, N.Y. 10011-4211.

Advertising Sales: write to the Advertising Coordinator at the above address.

Periodicals postage paid at New York, NY and at additional mailing offices.

POSTMASTER: Send address changes to English Today, Cambridge University Press, 100 Brook Hill Drive, West Nyack, N.Y. 10994-2133.

Japanese prices for institutions are available from Kinokuniya Company Ltd, P.O. Box 55, Chitose, Tokyo 156, Japan.

Contacting the Editor: Email Dr Tom McArthur at <Scotsway@aol.com> or write to him at 22-23 Ventress Farm Court, Cherry Hinton Road, Cambridge CB1 8HD, UK. Tel 01223245934.

Internet access This journal is included in the Cambridge Journals Online service which can be found at http://uk.cambridge.org/journals. For further information on other Press titles access http://uk.cambridge.org.

Designed and typeset by Peter Ducker. Printed in the United Kingdom at the University Press, Cambridge. 